\title{
Preliminary Discussion of the Teaching Reform for the Animation Professional
}

\author{
Xiaoshu Li \\ Zhengzhou University of Aeronautics \\ Zhengzhou, P.R.China, 450015
}

\begin{abstract}
It is the direction of the education reform that the teaching of animation professional is combined with the regional culture in Colleges and Universities. It is expound that the animation works must keep the originality and nationality, must improve economic efficiency and the students' enthusiasm. It has proposed that the teaching reform should be carried out from two aspects of the theory teaching and practice teaching. And then it points out that the key point of the animation professional of Henan universities combined with regional culture should be the Zhengzhou airport. It is discussed that the animation works how to express the combination of the airport with "Silk Road", and how to express the combination of the airport with Henan "Yu" culture. Finally, combined with the practice reform, it has made the preliminary results.
\end{abstract}

Keywords-arts; market economy; layout design in animated film and video

\section{INTRODUCTION}

There are many kinds of art majors, such as the fine arts, music, physical training and so on. Single from the fine arts to say, it can include many branches: the animation, industrial design, environmental design, landscape design and so on. In all of these specialized subjects, the animation is a art category that has combined the various disciplines.

Animation is a major that the practicality is particularly prominent. During the time in school, students need to study the theory knowledge and practice training of the painting, animation production in order to improve their manipulative ability. In these practices, painting is just a basic subject, the design and manufacture for animation and movie is a comprehensive and systematic training, and all these training theme combine with the local economy is very necessary. In the animation major teaching, from theory to practice to carry on reform is very important.

\section{SignifiCANCE OF THE ANIMATION PROFESSIONAL COMBINED WITH REGIONAL CULTURE}

Animation, in English called "cartoon", it means "make some pictures to move", the China's merry-go-round, shadow play is the embryo of "animation". In the minds of many people, the animation is service for children; it is a magic weapon which can make the children quiet. However, along with the emergence of «Frozen», «Zootropolis», «Big Hero 6» and other outstanding animations, they are not only attracted the children's eyes but also captured a huge number of adult viewers. These animations are also competing in the various awards of Oscar, and have put the glory in the awards ceremony. Now animation has gradually integrated the small range of entertainment play into everyone's life.

The education of animation's students is not only limited to explain the theory of books and the practice of pictures move, but also ought to combine with the local characteristics, divergent own thinking and use their own professional to carry on professional design. On the one hand, it can be reveal the major knowledge completely, on the other hand, the students can integrate into the social as early as possible, and make oneself on the top of the profession.

Combined with regional culture is the key to keep the originality of animation works. Pursuit of originality is an important measure to change the low lever, less number of our native animations. The uniqueness of the regional culture provides a basis for the original animation works. In the field of animation industry, integrate the regional culture into it and use the advantage of regional characteristic culture can improve the level of our original animation absolutely. The animation professional education in colleges and universities, should conform to this change and carry on educational reform.

Combined with regional culture is the necessary foundation that the animation works go to the world. Although Japan, Europe's animation art and industry is more advanced, we can not blindly worship them. If our teaching and practicing are revolved around Japanese model and European model, we will lose the essence of national culture and the position in the world. The regional culture is the foundation and composition of the national culture, combined with it is the necessary request to insist the national character.

Combined with regional culture is the important measure to make the animation works get economic benefits. Commercial animation film is an important part of animation, numerous facts at home and abroad are explained that one of the success secrets in commercial animation film is the regional culture element which can make audiences feel strange and curiosity.

Regional culture is a dope which can enhance learning enthusiasm of the cartoon major students in college and universities. To understand the home town's culture is the instinct of a man, add the elements of region culture in teaching can provide the enthusiasm of learning and creating of the students, it is better for improving the education quality. 


\section{KEY POINT OF THE ANIMATION PROFESSIONAL OF HENAN UNIVERSITIES COMBINED WITH REGIONAL CULTURE}

Henan province, located in the central China, it is the transportation hub of our country, has linked all the important cities of China. However, because it is a inland city, its disadvantage is inevitable: the messages resources' development and update can't keep up with Beijing, Shanghai and Guangzhou, the output of the new industries much larger than the supply and demand. On December 15, 2015, the Premier of Li Keqiang and the leaders of who are members of the regional Shanghai Cooperation Organization, they visit the city construction of Zhengdong New Distraction of Zhengzhou City together, and this behavior can promote the Henan's economic construction. Zhengzhou airport has become the first aviation economy experiment site and advanced area of national strategy, and it shows that Henan is developing from railway to airplane gradually. To build the "Memphis"[1] of China, is the basic objective of Zhengzhou airport construction. As a new port city, propaganda it by a big margin and high strength is necessary, and this is the time to give play to the animation professional students, using their special advantage to design the appearance of the airport, and also can make a short animation to play on the subway, television and so on. On the one hand, it can improve the brand awareness of airport and enhance the economic; on the other hand, the students also have their own professional training.

Zhengzhou airport is the key point of Henan university animation professional combined with regional culture. This is the rare chance to be provided by history.

\section{Main Contents of the ANimation Professional OF HENAN UNIVERSITIES COMBINED WITH REGIONAL \\ CULTURE}

Combination of animation major with regional culture should be start from theory and practice. This paper analyzes from the practice teaching.

From the point of professional teaching view, as a animation major freshman, their course are mainly fundamental courses, such as animation techniques, animation production and history and so on, these courses make the students to know the animation major's origin, development, application and so on. During sophomore year, the courses increase the sketch and the other hand-drawn practice courses to improve the students' handling ability. During junior year, the courses will be more subjective, such as layout design in animated film and video, animation films screenwriting and the other courses. All of the courses request the students inject their own thinking in the final works. For junior student, they have had plenty of theory knowledge and the handing ability is well, what they need is to reveal in the practice, closely connected with the market is the best way to training themselves.

Based on the principles and ideas to exercise self and improve the major knowledge, in the layout design course, in animated film and video course, fully are combined with the current market economy and closely integrated with Zhengzhou airport, to design a series of the propaganda posters and cartoons is the best way of teaching combined with regional culture. However, at the beginning, students' thinking is just on the word "airport", all ideas are about port and plane. The thinking is fixed in form and monotonous in content, that causes a phenomenon: the design fall into stereotypes and make the audience visual fatigue.

\section{A. Combination of Airport and Silk Road}

"Airport", the main function is to transport goods in the air, strengthen economic ties among the various countries, and this concept is as same as the ancient "Silk Road". The Chinese Silk Road was constructed under the western Han Emperor Wudi, it was the land channel based on the Chang an (now Xi an) as the starting point, through Gansu, Xinjiang, to Central Asia, West Asia, and connecting the Mediterranean countries[2]. In September 2014, the country puts forward the strategic plan of "One Belt and One Road", the "Silk Road economic belt" is to refer this channel and its diffraction regions. Liu Jiongtian, a member of the Chinese Academy of Engineering points out: "from Xian of the Western Han Dynasty to Luoyang of the Eastern Han Dynasty, China mainly output tea, paint and other products on the Silk Road. It also can say, our output is the industry advantage from east to west [3]". On this level, Henan can be the "Industrial hinterland"of the economic belt of the Silk Road.

The import and export goods are gradually increasing in airport and the variety of goods include electronic products, clothes materials and so on. The starting point of Silk Road is Xian, passing Gansu, Xinjiang and other cities to all parts of the world, the development of the airport provides the opportunities and challenges for Henan, through Henan, the Silk Road can be enlarged, at the same time, combined the ancient mysterious channel with modern port both could inherit the ancient cultural and propagate the modem civilization.

To take the brand building of modernization hub airport as the leading, the cultural construction as the core, let Henan's abbreviation combined with aviation, the Silk Road combined with airline as the basis points, propagate Zhengzhou's new type airport city, promote the fourth increasing pole of chinese economy, realize the historic leap from "land" to "heaven" of Henan.

\section{B. Combination of Airport and Henan Culture}

This is just a point of extension, from the perspective of region to see, "airport" builds on the transportation hub of Zhengzhou, and which is the provincial capital of Henan. Henan's short form is "YU", and this word is combined "YU" and "Xiang". Research on the separated word, use the visual word to be called Henan for short, it can not only show the characteristics of Henan, but also make people impression more profound. Using the naive image of elephant to design the word on behalf of Henan, it could display the "elephant" image, and could make people remember the relation between Henan and "Yuzhou".

The provincial capital of Zhengzhou is an inland city, it neither close to border nor coastal. The natural geographical disadvantage makes its exports lack of competitiveness in the international market, and it has been a bottleneck that restricts 
the development of inland region's open economy. But the airport economics will be the important breakthrough point for solving the problem of inland region to open economy. Through the study of the separated Chinese characters of "airport", it can use the aircraft image to express. The airport located in the central plains can be combined with Chinese characters"YU", the Chinese characters "XIANG"can stand for region,the "plane" can stand for the airport, using both of these harmoniously connected to give public to the Zhengzhou airport, meanwhile Henan will also be introduced to everybody.

The economic region of airport with their city is mutually promoted together. On the one hand, the development of airport drive the progress of the city and region, on the other hand, the airport depends on the construction and development of the city, and it is affected by the city size and lever. That is, the larger the city, the higher the development level, the greater the airport's cargo passenger flow, the development conditions are better. Big city, large population and high income will bring the benefit of the airlines, and will have a strong appeal to the air company.

\section{SHOWING OF THE RESULTS OF TEACHING REFORM}

In recent years, the author has done some experiments in combination with the airport at the course. Through the analysis of the horizontal and vertical of the "Airport", the students think that mode also expands in some way and designs a lot of good paintings. In this paper, we choose two paintings to analyzes, and both of these are the brand drawings of Zhengzhou airport.

The first painting, as shown in "Fig. 1". In this painting, the student make the design of cloud in the sky, after careful observation, you will find the cloud seems like a baby elephant, and the inspiration comes from the Henan broadcast and television's logo, it represents the modern culture feature of Henan broadcast and television. On the top left of the painting, is Taihang Mountains, a famous mountains of Henan, it is the eastern boundary of Loess Plateau, which has a representative meaning and also is a symbol of Henan's tourism and culture. In the center of the painting, it is a original scene reappearance of ancient silk road, there is not only a camel but also a person to lead the elephant to advance in the Silk Road in this painting. In the design process, the main consideration is that the elephant represents the Henan ancient culture, the old Silk Road is to take the camel as traffic tools, at that time, Henan was the most prosperous city in China. The old Silk Road and the modern Zhengzhou airport are the transportation; both of them can strengthen the connection of economic and culture from every country. The plane represents the Henan airport's air transportation business and is good at the development of Henan's economic and culture. On the right of the painting is the Luoyang's ancient city walls, it represents the Heluo culture and which is the core of Chinese traditional culture. Heluo culture has a long-standing history and well-established, broad and profound, it had been breeds the ancient civilizations of the Chinese nation, and in the thousand of years development times, it always be the main trend and source in the Chinese traditional cultural, play a vital role in the history[4]. Heluo culture's influence should not be underestimated until today.
The second painting, As shown in "Fig. 2". From the perspective of the whole works, it is looked at from inside of the cabin to outside, the Henan opera facial masks on the table shows the strong characteristics of Henan, look out from the window, there is a row of planes in order on the left, they are ready to fly, and we also can vaguely see the merchants and camels with goods in the desert. Put the planes and camels in the same painting, it is not only a contrast of the form but also a progress of the vision. In the Western Han Dynasty, people use the easy vehicles to transport goods, this can make China flow the goods with foreign countries and promote the economic development, beside that, the ideology, culture, food and the other fields of China also could spread abroad, that is why this road is called "Silk Road". This road not only promotes the economic but also spreading the culture! With the development of science and technology, modern transportation has replaced the camels slowly, and shortened the cargoes circulation time, enhanced the efficiency. It has realized the qualitative leap from the land to the air, it has provided a great help to the economic and cultural construction.

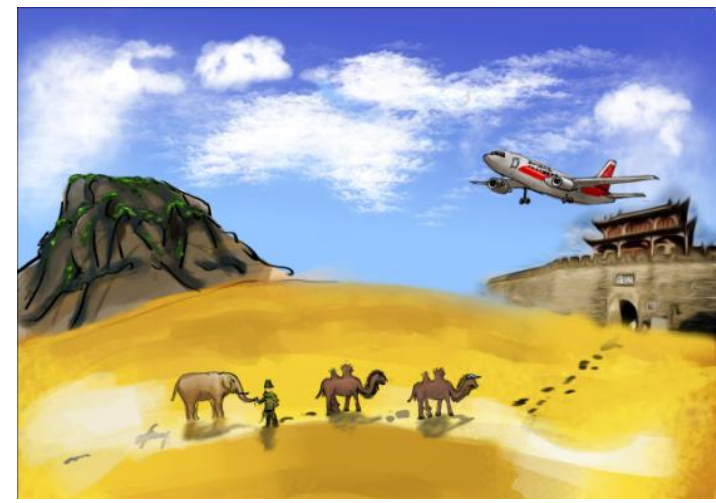

Fig. 1. Scheme one of the Zhengzhou Airport's brand design

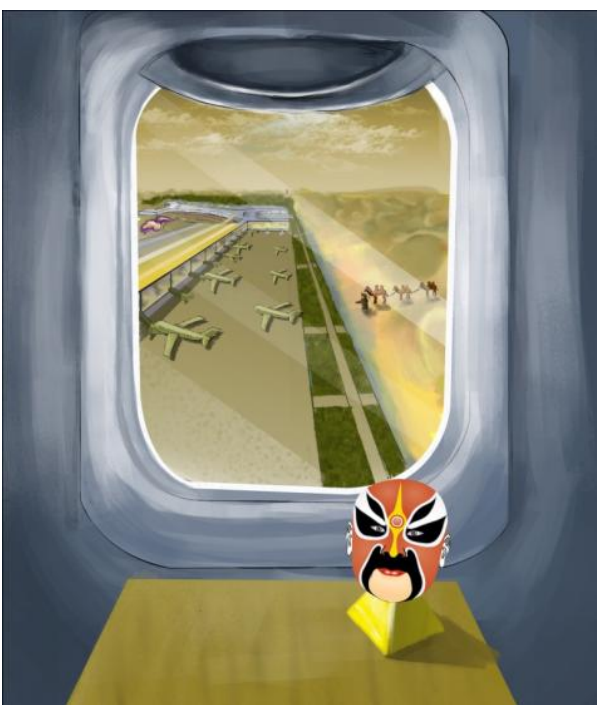

Fig. 2. Scheme two of the Zhengzhou Airport's brand design

\section{CONCLUSION}

The two paintings have different style, one painting describes the "airport" from the ancient time, the other 
describes it from the modern time, and they finely combine the ancient time and the modern time, in the same time, the two paintings provide the design inspiration for the airport design unit and finally arrive the purpose of the course reform, meanwhile, the students also get a good practice.

\section{REFERENCES}

[1] SHEN Lu-ying. Study on the Development Patterns of World Airport Economy[J]. World Regional Studies, 2008, (3): 20-23.

[2] LIU Ying-sheng. The Silk Road [M].Jiangsu: Jiangsu Peoples Publishing Limited, 2014.

[3] HU An-gang, MA Wei, YAN Yi-long. Connotation, Definition and Passage of "Silk-road Economic Belt" Strategy[J]. Journal of Xinjiang Normal University (Philosophy and Social Sciences), 2014(04): 3-8.

[4] LIANG Ya-ming. Symbol Application of Heluo Culture in Tourism Creative Product Design[J]. Packaging Engineering, 2015(24): 129-132. 